these doubts but maintained that the study "does not include fake data".

"I'm at a total loss to look at anything in the Gaskin paper or its conclusions that are not based on fabricated data or the concealment of their own data," says Lewis, who claims he was forced out of the EPA in retaliation for his research into the health impacts of sewage sludge.

In 2002, Lewis and his colleagues published a study in the journal BMC Public Health documenting reported health problems among more than 48 people who lived near fields where 'Class B' sludges - the most common and least sanitized - were applied ${ }^{2}$. Some 25\% of those surveyed were infected by Staphylococcus aureus, which contributed to two people's deaths. This research was cited in the 2002 NAS report as well, although the report stated that there was no "documented scientific evidence" to substantiate reports of human illnesses or death. The academy said that it was not charged with evaluating human health claims but went on to acknowledge a "persistent uncertainty" about health impacts.

The NAS report recommended that the EPA conduct a new survey of chemicals and pathogens in sewage sludge, begin systematically tracking health complaints, and conduct epidemiological studies to assess the impacts of biosolids. The EPA has yet to implement these recommendations, although officals say a new survey of toxic chemicals found in sludges is due out later this year.

Last year, a team led by epidemiologist Sadik Khuder of the University of Toledo in Ohio published similar findings to those of Lewis's team. Their larger study found that the risk of various health problems correlated with the proximity to farms where Class B sludges had been applied ${ }^{3}$.

"We have no idea what's going into the waste-stream," says Murray McBride, director of Cornell Waste Management Institute in Ithaca, New York. He says that there are unknown risks from cleaner 'Class A' sludges as well, because the sterilization process doesn't kill all the pathogens and doesn't affect a host of other chemicals used in modern industry. McBride says that the scientific community and regulatory agencies have been slow to address these questions because of the huge economic and institutional investment in the biosolids programme. "There's a vested interest now in keeping this land application going," he says. Jeff Tollefson

\footnotetext{
1. Gaskin, J. W., Brobst, R. B., Miller, W. P. \& Tollner, E. W. J. Environ. Qual. 32, 146-152 (2003).

2. Lewis, D. L., Gattie, D. K., Novak, M. E., Sanchez, S. \&

Pumphrey, C. BMC Public Health 2, 11 (2002).

3. Khuder, S. et al. Arch. Environ. Occup. Health 62, 5-11 (2007).
}

See Editorial, page 258.

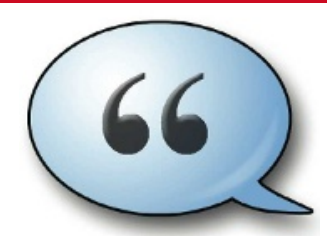

HAVE YOUR SAY

Comment on any of our news stories, online.

www.nature.com/news

\title{
German universities bow to public pressure over GM crops
}

Scientists have decried the decision by two German universities to pull the plug on field trials of genetically modified (GM) crops, calling it a "disgraceful" interference with scientists' freedom to research.

"I am not happy at all with this decision," says Stefan Hormuth, president of the Justus Liebig University in Giessen, Hesse. "Unfortunately, we were no longer able to deal with the massive opposition from politicians and the general public. The university has a reputation in the region that we cannot risk losing."

Last month, the university announced that it would stop its planned cultivation of insect-resistant GM maize in nearby GrossGerau after activists occupied the 1,500-squaremetre field. Another local field trial of GM maize, in Rauischholzhausen, was also stopped because of massive protests from the public and local politicians. Both trials had been approved by the national consumer protection and food safety body (BVL) and were to be conducted on behalf of Germany's authority for agriculture variety and seed affairs.

Earlier in April, the rector and external advisory board of Nürtingen-Geislingen University in Baden-Württemberg "urgently recommended" that a faculty member stop his field trials on insectresistant and fungal-resistant GM maize. The experiments, which were also approved by the BVL, had been going on since 1996. "We have always been very critical of this kind of research," says economist Werner Ziegler, the university's rector. "Lately things got out of control. There were e-mail attacks, vandalism, intimidation and personal threats. People started calling us 'Monsanto University".

The final straw, Ziegler says, was when the local population brought food and blankets to activists occupying the university's Oberboihingen test site. Local media and supporters hailed the illegal action as a brave act of civil inconvenience.

The university's experiments were led by Andreas Schier, who studies fungal toxins in maize. Although legally the university could not have forced him to stop the field trials, he says he eventually gave in because the pressure on him had become too great. "Scientifically, there was no reason whatsoever to discontinue the experiments," Schier says. "But scientific arguments don't count in a climate of mass hysteria."

Schier claims that Ziegler and members of the advisory board threatened to publicly distance themselves from him and his research if he were to continue. "I couldn't stand the pressure any more," he says.

The incidents reveal a new level of public hostility to plant genetic engineering in Ww Germany, says Heinz Saedler, y) a director at the Max Planck (1) Institute for Plant Breeding Research in Cologne, which this year is not cultivating GM crops either. "It is a very sad thing that some universities here haven't got the backbone to withstand illegal activism and public pressure," he says. "I honestly don't have much hope left for the future of academic research on GM crops in Germany."

"If it is indeed true that universities in Germany hinder faculty members from doing field research on GM crops for fear of being vandalized by anti-GM activists, then this is disgraceful," says Vivian Moses, a visiting professor of biotechnology at King's College London.

Vandalism and the destruction of GM crops have been common in Germany and elsewhere in Europe since field trials began 20 years ago. As a result, academic research in the field is becoming scarcer. Germany hosts around a third of the European field trials this year, on an area of just 30 hectares. Europe's GM crop-cultivation research is almost negligible compared with that in the United States, Brazil and Canada.

"Work in the field is no longer appreciated because there is a perception that commercially it doesn't lead anywhere, at least in the short term," says Moses. "We need to face up to reality: is the global food crisis upon us, and must we take action, or will Europe continue to act as an ostrich, doing its best to ignore modern agricultural technology?"

Quirin Schiermeier 